International Journal of Instruction e-ISSN: 1308-1470 • www.e-iji.net

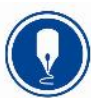

January $2020 \bullet$ Vol.13, No.1

p-ISSN: 1694-609X

pp. 551-566

Received: 07/01/2019

Revision: 26/08/2019

Accepted: 01/09/2019

OnlineFirst:19/11/2019

\title{
E-Task-Based Learning Approach to Enhancing 21st-Century Learning Outcomes
}

\author{
Ali M. Al Kandari \\ Dr., Faculty of Education - Kuwait University, Kuwait, a.habib@ku.edu.kw

\section{Mousa M. Al Qattan} \\ Dr., Faculty of Education - Kuwait University, Kuwait, mousaalqattan@yahoo.com
}

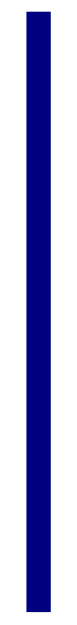

\begin{abstract}
Building a learning environment for students to meet educational objectives is a major challenge facing education stakeholders, particularly teachers. This study aimed to design and implement an e-task-based approach (eTBA) and examine its impact on 21st-century learning outcomes (21st-CLOCs) - namely, critical thinking and problem solving, collaboration across networks, agility and adaptability, effective communication, initiative and entrepreneurialism, accessing and analyzing information, and curiosity and optimism-in a kindergarten sample $(\mathrm{N}=22)$. A mixed-methods approach was adopted. Observation forms and rubrics were designed and used to collect evidence on 21 st-CLOCs, and a repeatedmeasures analysis of variance was used to measure patterns of progress during a 24-week experiment. Over the course of 12 experience task activities, the 21stCLOCs developed significantly. Children's overall learning outcomes improved as a result of the e-task-based approach applied in this study. Experiencing three task activities was enough for children to cope with the outcomes, with respect to children's individual variations. Further research is required to apply the e-task based approach to different contexts and grade levels.
\end{abstract}

Keywords: 21st-century learning outcomes, 21st-century skills, authentic assessment, instructional design, learning environment, task-based approach

\section{INTRODUCTION}

The process of change in school culture to meet the demands of the $21^{\text {st }}$ century is multifaceted, and it burdens the education system, curriculum and instructional designers, and teachers with the responsibility of identifying, implementing, attaining, and maintaining $21^{\text {st }}$-century learning outcomes (21 ${ }^{\text {st }}$ CLOCs). Chalkiadaki (2018) stated that stakeholders have engaged in heated discussions over which skills and competencies should guide $21^{\text {st }}$-century educational policy and practice. They aim to have children grasp $21^{\text {st }}$-century skills $\left(21^{\text {st }}-\mathrm{CSs}\right)$ in terms of literacy, competencies, and

Citation: Al Kandari, A. M., \& Al Qattan, M. M. (2020). E-Task-Based Learning Approach to Enhancing 21st-Century Learning Outcomes. International Journal of Instruction, 13(1), 551-566. https://doi.org/10.29333/iji.2020.13136a 
academic outcomes (Ajlouni \& Aljarrah, 2012; Ananiadou \& Claro, 2009; Chau, 2014; Sanabria \& Arámburo-Lizárraga, 2017). Wagner (2008) asked an essential question: Which qualities will our graduates need in the $21^{\text {st }}$ century for success in college, careers, and citizenship? Indeed, putting $21^{\text {st }}$-CSs into practical use is a challenge for most stakeholders. An extensive review of the literature on $21^{\text {st }}$-CSs suggests that education decision makers must acknowledge that the academic paradigm of the past is not enough for the present or the near future (Partnership for $21^{\text {st }}$ Century Skills, 2009; Sanabria \& Arámburo-Lizárraga, 2017). Several countries' standards stress creativity, critical thinking, problem solving, communication, and so on; however, few curricula bring these standards to life as learning outcomes, and few countries assess them via either national or state tests or in classroom practice (Pearlman, 2010). Thus, educational institutions and schools have started to rethink their aims and goals and infused $21^{\text {st }}$-CSs into their educational regulations, plans, curricula, instruction, and learning environments (Bell, 2010). The learning outcomes approach covers the range of necessary outcomes and emphasizes the integration of those outcomes in the teaching/learning environment, processes and practices. It refers to complex abilities that are demonstrable and produce observable results. The education paradigm in the $21^{\text {st }}$ century has attracted stakeholders' attention in different sectors who aim to have students grasp $21^{\text {st }}$-century skills in terms of literacy, competencies, and academic outcomes (Dede, 2010; Jang, 2016; Nir et al., 2016; Palaiologou, 2016; Patrick, 2013; Sanabria \& Arámburo-Lizárraga, 2017; Wagner, 2008). Researchers have identified critical factors that must be aligned to ensure a successful learning environment (Bell, 2010; Chau, 2014; Coklar \& Sahin, 2014; Jang, 2016; Lombardi, 2007). For the $21^{\text {st' }}$ CSs movement to improve schools, major changes in curriculum content knowledge and competencies as well as teacher training are necessary. The $21^{\text {st }}$-century school also incorporates multiple literacies and authentic assessments (Ananiadou \& Claro, 2009; Coklar \& Sahin, 2014; Lombardi, 2007; Rotherham \& Willingham, 2009).

The literature was reviewed to explore the development of the progressive education evident in the domain of $21^{\text {st }}$ century skills, focusing on fostering deep knowledge as well as academic skills, thinking skills, and personal skills. The results revealed that most previously suggested changes in curriculum, instruction, and pedagogy have not resulted in sustainable, system-wide change, and a large disparity is evident between declarations about innovative efforts in teaching and learning and their actual implementation. Technically, the $21^{\text {st }}$-CLOCs identified by researchers are inconsistent with current curriculum and practices in Kuwait, creating a substantial challenge in infusing these skills frameworks into educational practice and policy ( $\mathrm{Al}$ Kandari \& $\mathrm{Al}$ Qattan, 2018; Safar et al., 2017). Kindergartens in Kuwait now have all the means necessary to move beyond being taught $20^{\text {th }}$-century competences. The primary barriers to altering curricula and practice are conceptual, instructional design, the learning environment, and assessment. Thus, designing, implementing, and assessing the electronic-task-based-approach will be the focus of this study. 


\section{Study Questions}

1. What is the impact of the e-task-based approach (eTBA) learning environment designed for this study on children's $21^{\text {st }}$-CLOCs?

2. Are there any patterns in children's performance over the 12 experience tasks in relation to their $21^{\text {st }}$-CLOCs?

\section{Objectives of the Study}

1. Provide theoretical and practical guidelines to design a task-based learning environment in which children are engaged in relevant and meaningful learning.

2. Explore the inclusion of fundamental skills that can be incorporated in task-based learning. The study will aggregate the $21^{\text {st }}-\mathrm{CSs}$ identified and classified by scholars, such as critical thinking and problem solving, collaboration, agility and adaptability, initiative and entrepreneurialism, effective communication, accessing and analyzing information, and curiosity and optimism. These will be developed into learning outcomes.

3. Create a high-quality learning environment in which kindergartens develop lifelong academic, thinking, and personal skills through provocative task assignments that promote children-centered and active learning. In doing so, the learners will develop and exhibit $21^{\text {st }}$-CLOCs.

4. Design valid and reliable authentic assessment tools, such as observation forms and rubrics, and put them into practice to measure children's fundamental skills as they present their e-portfolio artifacts.

5. Investigate improvements that may occur due to children's engagement and interaction with the digital task assigned for this study.

\section{Significance of the Study}

The importance of this study lies in its focus on emerging trends in the development of the kindergarten learning environment to enhance $21^{\text {st }}$-century learning outcomes. The researchers employed an e-task-based learning approach (eTBLA) in a realistic context. The results of the study can help decision makers provide eTBA as a new educational teaching and learning method in kindergarten. The outcome of this study can be used to provide guidelines for educators in leading science, mathematics, and literature curriculum activities in the form of digital or e-tasks to be completed anywhere and to be presented in classroom. In addition, the assessment rubric sets an explicit range of expected performance criteria; the rubric can be adopted, modified, and customized to new learning contexts, regardless of the specific curriculum content or children's grade level. Finally, the eTBLA represents an important addition to the literature in the field of integrating information communication technology (ICT) into relative practices, especially considering the scarcity of scientific studies in this area, particularly in the Middle East region in general and the state of Kuwait in particular. 


\section{CONTEXT AND REVIEW OF LITERATURE}

\section{Utilizing ICT to Enhance Learning Outcomes}

Recently, in the USA, the National Association for the Education of Young Children and the Fred Rogers Centre reported that developmentally appropriate practices must guide decisions about whether and when to integrate technology and interactive media into early childhood programs. This report emphasized that technology can enhance early childhood practice when integrated into the curriculum and daily kindergarten routines (Nikolopoulou, 2014). An extensive review of the literature on $21^{\text {st }}$-CSs apprehension suggested that educators and teachers strongly influence the use of ICT to both enhance and extend existing classroom practice and changes in terms of emerging forms of activity to complement or modify practices. Today's students access and utilize ICT for entertainment, but they are also expected to be able of using emerging technologies in academic life (Al Kandari, 2013; Al Rewashed et al., 2017; US 21st Century Workforce Commission, 2000; Palaiologou, 2016). Patrick (2013) noted that, although today's children understand how to access and utilize these tools, they are not truly ICT literate. Adams \& Hamm (2019) insisted that innovation and collaboration are considered to be mental tools for enhancing learning mathematics, science and technology, they suggested solutions and lesson plans to prepare tomorrow's innovators. Thus, additional efforts are needed to expand the competences required for academic purposes, which requires authentic context-relevant exercises.

\section{$21^{\text {st }}$-century Outcomes}

The Framework for $21^{\text {st }}$ Century Learning, developed in 2009 by the Partnership for $21^{\text {st }}$ Century Skills, defined $21^{\text {st }}$-CSs (Dede, 2010). It structures $21^{\text {st }}$-CSs as a collective vision of the skills, knowledge, and expertise necessary for learners to generally succeed in contemporary work and life. The framework is divided into a number of $21^{\text {st }}$-CLOCs, including key subjects and $21^{\text {st }}$-century themes; learning and innovation skills; information, media, and technology skills; and life and career skills. Learning and innovation skills distinguish learners ready to face complex life and work experiences from those who are not. These skills include creativity and innovation, critical thinking and problem solving, communication, and collaboration. The framework also identifies several $21^{\text {st }}$-century support systems aimed at making the learning experience relevant, engaging, and personalized (Partnership for $21^{\text {st }}$ Century Skills, 2009). In his book The Global Achievement Gap, Wagner (2008) identified seven survival skills: (1) critical thinking and problem solving; (2) collaboration across networks and leading by influence; (3) agility and adaptability; (4) initiative, and entrepreneurialism; (5) effective oral and digital communication; (6) accessing and analyzing information; and (7) curiosity and imagination. Jang (2016) pursued a growing interest in the frameworks for $21^{\text {st }}$-CSs. His analysis of 109 skills, categories of knowledge, and work activities revealed 18 skills, 7 categories of knowledge, and 27 work activities important for STEM workers. Moreover; based on a literature review of $4021^{\text {st }}$-century frameworks, Chalkiadaki (2018) concluded that the $21^{\text {st }}$ century is primarily characterized by the evolution of technology and ICT, globalization, and a need for innovation, thereby highlighting the need for students to develop relevant skills and competencies. 
To maximize the quality of student learning outcomes, it is necessary to develop reliable learning opportunities in ways that provide learners with challenging experiences that (1) are authentic, real-world and relevant, (2) are constructive, sequential and interlinked, (3) require students to use and engage with progressively higher-order cognitive processes, (4) are all aligned with each other and the desired learning outcomes, and (5) provide challenges and elicit interest and the motivation to learn, according to (Meyers \& Nulty 2009; Al Kandari \& Al Qattan 2018). Educational researchers have demonstrated that students were more motivated when involved in authentic learning even if they faced some challenges and frustrations (Lombardi, 2007; Bell, 2010). Chau (2014) noted that as many studies have shown, the factors affecting students' motivation are the social structure and culture that give academic disciplines their meaning. Students drive their own learning through inquiry, according to $\mathrm{Al}$ Kandari (2013).

\section{Learning Context}

The study of trends in student achievement, TIMSS' first priority in characterizing the educational context, is to gather data relevant to community and national policies, home contexts, school contexts, classroom contexts, and student attitudes toward learning that can help interpret achievement changes (Mullis \& Martin, 2019). Interacting with others in a social learning context encourages the engagement of more advanced thought and the sharing of ideas. Patrick (2013) explored the possibility of implementing a constructivist learning environment as the basis for enabling students to acquire $21^{\text {st }}$-CSs and competencies within the context of a developing country. He suggested an interactive learning environment as a recommended approach.

Lewin (2000) emphasized the importance of implementing technology at a young age so that students can be prepared for the future. Sanabria and Arámburo-Lizárraga (2017) added that learners in the digital age need to develop relevant skills in non-formal and formal contexts to reduce the gap between the academic context and the marketplace on the one hand and the revolutionary wave of self-taught networked learners on the other. Nir et al. (2016) analyzed the development of progressive education evident in $21^{\text {st }}$ CLOCs, revealing that most previously suggested changes in pedagogy have not resulted in sustainable, system-wide change, and a large disparity is evident between declarations about innovative pedagogies and their actual implementation. Al Rewashed et al. (2017) reported that the current educational system does not teach essential competencies in a way that is relevant and required for students' successful future. As Loveland (2017) summarized, soft skills development in school settings are often difficult to quantify and assess. Thus, in today's world of digital technology use in the early years, educators should re-examine the way students learn and how learning communities should be designed and structured. Walker (2017), in his book Teach like Finland, referred to joy and happiness in classrooms, aligned with a softer approach of short school days, light homework, and little standardized testing to ensure great learning outcomes.

If learning activities are well supported by teachers and parents, then higher levels of learning outcomes are likely to occur (Coklar \& Sahin, 2014). According to Hyun and Davis (2005), exploratory talk is important to support students' construction of 
knowledge by allowing them to expand their learning experiences. The authors thus emphasize the re-conceptualization of students' learning settings and pedagogy as they engage with digital technologies in the classroom and at home. One of Palaiologou's (2016) key findings is that parents feel that they are digitally literate and can use digital technologies as part of their everyday lives, including scaffolding their children's learning. Wildenger and McIntyre (2012) found that early education experiences and family involvement in preparation activities are important for children's sociobehavioral outcomes in kindergarten.

However, shifting to $21^{\text {st }}$-CLOCs requires new roles and appearances in core learning contexts, such as students, teachers, instruction, and assessment. Scholars in certain fields emphasize critical thinking, problem solving, communication skills, teamwork, and professionalism - beyond mere knowledge about the field itself - to enhance the $21^{\text {st }}$ century's educational paradigm. However, advocates of $21^{\text {st }}-\mathrm{CSs}$ often underestimate the magnitude of the challenge of teaching these skills in the context of teaching meaningful content (Rotherham \& Willingham, 2009; Sanabria \& ArámburoLizárraga, 2017). To use $21^{\text {st }}$-CSs to improve schools, major changes in curriculum content, knowledge, competencies, teacher training, and assessment are necessary (Rotherham \& Willingham, 2009). Lombardi (2007) identified eight critical factors that should be aligned to ensure a successful learning environment: (1) goals, (2) content, (3) instructional design, (4) learner tasks, (5) instructor roles, (6) student roles, (7) technological affordances, and (8) assessment as well as parental engagement (Coklar \& Sahin (2014).

\section{METHOD}

\section{Context of the Study}

To understand the situation examined in this study, a brief background of kindergarten in Kuwait is warranted. The Ministry of Education administers kindergarten, which is compulsory and free. It starts at age four and has two levels. Only female teachers and supervisors are employed to teach at this level, and they must have a bachelor's degree in early childhood education or psychology. Each classroom has one teacher and one coteacher. During the school year, children are exposed to different content/subject areas known as "experiences," which are meant to help children meet the national curriculum objectives. They include basic Arabic, simple English, science, math, art, and music.

\section{Procedure}

To prepare the learning opportunities assumed to enhance $21^{\text {st }}$-CLOCs via eTBA, a conceptual model was designed to guide the study's procedures as well as the learning environment. The model used ICT to engage children in their science homework through e-tasks. The instructional design focused on how to engage children mentally in digital assignment tasks, enabling children to demonstrate their $21^{\text {st }}$-CLOCs while presenting their assignments. During this process, we observed and videotaped the classrooms, modified the observation forms and rubric for assessment, and evaluated children's progress. 


\section{Participants}

Participants included two kindergarten-level classrooms consisting of 22 children (13 girls and 9 boys). One classroom was used for the pilot study prior to this study. Implementing the study at the kindergarten level was done for several reasons. First, specialists agree that children's personalities are formed in the first five years, and their intelligence is formed by the age of four. Second, the growth of basic developmental skills is believed to occur at this stage (Shawareb, 2011). The study was limited to a sample of 22 children from one kindergarten.

\section{Instruments}

The researchers designed a rubric to score children's progress and analyze the data. The rubric describes Wagner's (2008) seven survival skills. However, it was aggregated to align with what Loveland (2017) described as foundation skills, including academic skills, thinking skills, and soft skills. Geisinger (2016) suggested that many skills comprising the different models of $21^{\text {st }}$-CSs overlap considerably, as might be expected; many skills could be combined. The rubrics were coded and analyzed ( 22 children $\mathrm{x} 12$ tasks $=264)$. Three-point scales were used $($ exceed $=3$; meet $=2$; and poor $=1$; see Table 1)

\section{Table 1}

The 21st-Century Skills Rubric: Description of the Designated Skills, within Three Levels of Progress Outcome

\begin{tabular}{|c|c|c|c|c|c|}
\hline \multirow[t]{2}{*}{ Personal skills } & \multirow[t]{2}{*}{ Expected outcomes } & \multirow{2}{*}{$\begin{array}{l}\text { Examples: sign, responses, } \\
\text { indicators }\end{array}$} & \multicolumn{3}{|c|}{ Frequencies } \\
\hline & & & $\begin{array}{l}\text { Exceed } \\
3\end{array}$ & $\begin{array}{l}\text { Meet } \\
2\end{array}$ & $\begin{array}{l}\text { Poor } \\
1\end{array}$ \\
\hline $\begin{array}{l}\text { 1-Critical } \\
\text { thinking and } \\
\text { problem solving }\end{array}$ & $\begin{array}{l}\text { Act of making something } \\
\text { new; analysis and } \\
\text { synthesis of thought }\end{array}$ & $\begin{array}{l}\text { Apply know-how: Use science } \\
\text { concepts; use new icon }\end{array}$ & & & \\
\hline $\begin{array}{l}\text { 2-Collaboration } \\
\text { across networks }\end{array}$ & $\begin{array}{l}\text { Actively engage with } \\
\text { peers, teachers }\end{array}$ & $\begin{array}{l}\text { Converse on CK concepts with } \\
\text { peers; share CK; offer help in CK }\end{array}$ & & & \\
\hline $\begin{array}{l}\text { 3-Agility and } \\
\text { adaptability }\end{array}$ & $\begin{array}{l}\text { More focus on process of } \\
\text { learning, rather than } \\
\text { content }\end{array}$ & $\begin{array}{l}\text { Transfer CK \& skills across } \\
\text { contexts; use a variety of ICT } \\
\text { devices }\end{array}$ & & & \\
\hline $\begin{array}{l}\text { 4-Effective } \\
\text { communication }\end{array}$ & $\begin{array}{l}\text { Effective oral and digital } \\
\text { communication }\end{array}$ & $\begin{array}{l}\text { Voluntarily present tasks; use new } \\
\text { tools and icons; be delighted with } \\
\text { new idea; easily handle } \\
\text { unsuccessful trials }\end{array}$ & & & \\
\hline $\begin{array}{l}\text { 5- Initiative and } \\
\text { entrepreneurialis } \\
\mathrm{m}\end{array}$ & $\begin{array}{l}\text { Take risks, like trying } \\
\text { new ideas }\end{array}$ & $\begin{array}{l}\text { Present findings via ICT; coach } \\
\text { peers; reflect on own/others' work }\end{array}$ & & & \\
\hline $\begin{array}{l}\text { 6-Accessing and } \\
\text { analyzing } \\
\text { information }\end{array}$ & $\begin{array}{l}\text { Use ICT as learning } \\
\text { knowledge aids }\end{array}$ & $\begin{array}{l}\text { Access website; navigate; build e- } \\
\text { portfolio; add new knowledge }\end{array}$ & & & \\
\hline $\begin{array}{l}\text { 7-Curiosity and } \\
\text { Optimism }\end{array}$ & $\begin{array}{l}\text { Peruse knowledge with } \\
\text { inspiration and joy }\end{array}$ & $\begin{array}{l}\text { Ask what if Qs; show enjoyment, } \\
\text { genuine wonder, and excitement } \\
\text { for the purpose of knowing and } \\
\text { inquiring; gladly attempt to } \\
\text { overcome challenges; view failure } \\
\text { as temporary situation }\end{array}$ & & & \\
\hline
\end{tabular}




\section{Validity and Reliability}

After the rubric was developed, extensive revisions were made to ensure reliability and validity. Six professors, three experienced teachers and three supervisors, reviewed the rubric before and after the revisions. The rubric was tested using a pilot study, and interrater reliability was used to assess the degree to which researchers and classroom teachers agreed on assessment methods. Based on four weeks of pilot data, the Pearson correlation was used to compare researchers and classroom teachers (Jonsson \& Svingby, 2007); the value for $21^{\text {st }}$-CLOC was $r=0.70$. The reliability of the $21^{\text {st }}-$ CSs rubric was examined using Cronbach's alpha $(\alpha=0.73)$.

\section{Implementation}

The Kuwait National Curriculum for Kindergarten was used; it was modified and integrated with digital resources.

Experiences content

Physical science

- Properties of objects and materials

- Position and motion of objects

- Light, heat, electricity, and magnetism

Life science

- Characteristics of organisms

- Life cycles

- Organisms and environments

Earth and space science

- Properties of earth materials

- Objects in the sky

- Changes in the earth and the sky

Instructional design

Meyers and Nulty's (2009) instructional principles were considered to develop courses in ways that provide learners with eTBA that (1) are authentic, real-world, and relevant; (2) are constructive, sequential, and interlinked; (3) require children to use and engage with progressively higher-order cognitive processes; (4) are all aligned with each other and the desired learning outcomes; and (5) provide challenges and elicit interest and the motivation to learn.

Classroom settings

To ensure the implementation of e-tasks, the classroom settings were integrated. Every day, teachers explained their lessons, conducted hands-on activities, logged on to the Internet, and used the interactive board. children logged on to the classroom's website 
and accessed their personal e-portfolios. They also completed specific e-tasks. The teachers selected volunteers to share their learning and reflect on what they had done with the rest of the class.

Home settings

Given parents' important role in this study, two meetings with parents $(\mathrm{N}=22)$ were arranged to inform, explain, and ensure their involvement. During the second meeting, teachers and parents exchanged emails, phone numbers, children' IDs, and information on how to use the website at home with their children.

\section{ICT environment}

The classroom was equipped with the technology needed for the ICT learning environment, including projectors, an interactive board, a teacher desktop, and a wireless internet connection to enable children to log on to the classroom website in kindergarten and at home. Each child was provided with a tablet PC.

\section{Preparing teachers}

We conducted intensive meetings with the teachers and co-teachers to improve their knowledge and pedagogical skills related to conducting student-centered evidence-based assessments, using observation forms and rubrics, and using ICT as a learning tool. The training also included an explanation of the philosophy behind the use of technology and $21^{\text {st }}$-CLOCs and the eTBA.

\section{Preparing the settings}

Prior to this study, a 4-week pilot study was conducted to test the rubric, settings, and modified curriculum for teachers' and children' performance. The pilot study helped assess children's practices, parents' involvement, teachers' ICT practices, and the school administration's role. We modified the prepared settings based on the pilot study results.

\section{Assessment and Data Collection}

Once the settings were set, we visited every 2 weeks to carry out observations and monitor performance. The study lasted 24 weeks. Every 2 weeks, children covered an experience from the national curriculum and used ICT to complete eTBA activities. A rubric was used to grade collected data for analysis. Cross-coding among researchers and teachers was performed to ensure reliability in assessing the children. All children's e-portfolio artifacts (i.e., videos, images, and e-links) were collected and coded for analysis. All difficulties or obstacles were recorded during this study to develop better recommendations for the future. In addition, 12 videos of the classroom (one per task) helped us observe children and teachers working together on tasks and provided deep insights into the TBA learning environment.

\section{FINDINGS}

The first question focused on the eTBA and how it provided kindergarteners with opportunities to acquire $21^{\text {st }}$-CLOCs. A descriptive statistical analysis was performed. 
The means and standard deviations of the 22 children's $21^{\text {st }}$-CLOCs are reported in Table 2, which shows improvement along the 12-experience e-task activities (i.e., Experience 1 mean $=1.91$; Experience 12 mean $=2.72$ ). The field notes from the 12 experience task activities also indicated that children were slow and faced some challenges, mainly in terms of utilizing ICTs, navigating and exploring the classroom web, and engaging in assignment task activities. Figure1 reveals that the scores on the first three experience tasks increased slowly. By the Experience 4 task, the mean score rose to 2.40, and it continued to increase consistently through the Experience 12 task (mean $=2.72$ ). Thus, children were able to follow up and become faster in terms of completing the tasks without hesitation, and ICT use became an academic habit. This result is affiliated with Vygotsky's zone of proximal development, where there is no set age or developmental stage when children are ready to gain complex thinking skills.

Table 2

Descriptive Statistics Experience Task Activities

\begin{tabular}{lllllllllllll}
\hline & Task & Task & Task & Task & Task & Task & Task & Task & Task & Task & Task & Task \\
& 1 & 2 & 3 & 4 & 5 & 6 & 7 & 8 & 9 & 10 & 11 & 12 \\
\hline M & 1.91 & 1.98 & 2.10 & 2.40 & 2.50 & 2.52 & 2.58 & 2.63 & 2.65 & 2.73 & 2.62 & 2.72 \\
SD & 0.48 & 0.44 & 0.46 & 0.42 & 0.38 & 0.42 & 0.32 & 0.39 & 0.25 & 0.32 & 0.20 & 0.25 \\
\hline
\end{tabular}

The second question was whether a significant pattern emerged in children's $21^{\text {st }}$ CLOCs over the 12-experience e-task activities. A one-way within-subjects repeatedmeasures ANOVA was conducted to compare the effects of the 12 experience tasks (one experience every 2 weeks) on children's $21^{\text {st }}$-CLOCs in the learning environment designed for this study. A repeated-measures ANOVA with a Greenhouse-Geisser correction determined that the mean $21^{\text {st }}$-CSs differed significantly between experience task time points $(\mathrm{F}(2.93,49.86)=15.23, p<0.005)$.

Post hoc tests using the Bonferroni correction revealed insignificant development in children's $21^{\text {st }}$-CLOCs from Experience 1 through Experience 3 (means $=1.91,2.02$, and 2.10, respectively; $p=0.149$ ). However, a significant increase in mean scores 
emerged steadily starting with Experience 4 and continuing through Experience 12.

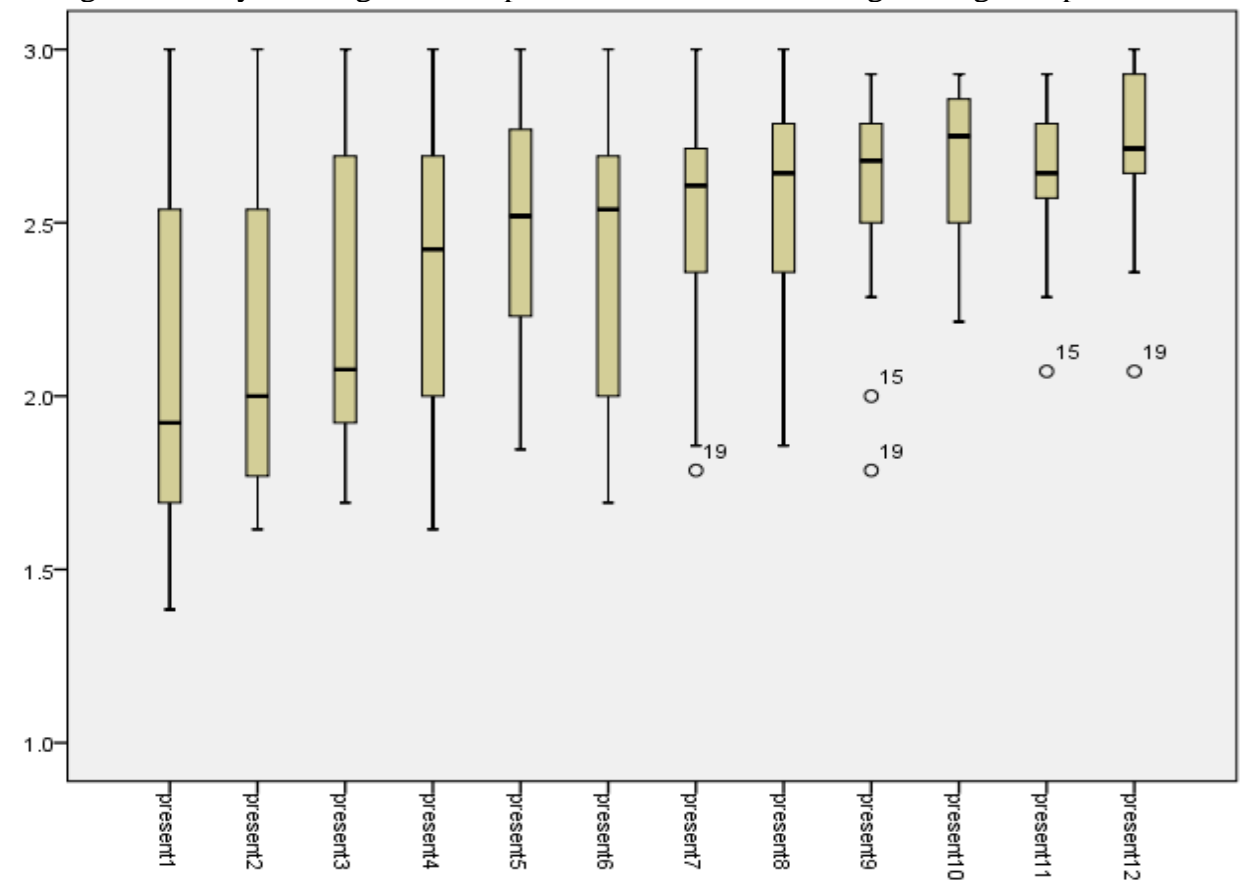

Figure 1

Mean Scores for Each Experience Task Activity for the Whole Class

Table 2 also shows the means, ranging from the Experience 1 task $($ mean $=1.91)$ to Experience 12 (mean $=2.72$ ). Notably, the maximum mean is 3 points, which was achieved by some children in almost all experience tasks. Thus, some children come to kindergarten with ICT skills.

However, the standard deviations (SD) for Experiences 1 through 4 ranged between 0.42 and 0.48 , which is relatively high for the maximum point $=3$ and reflects the variation in children's $21^{\text {st }}$-CS development. Meanwhile, the SD for Experiences 8 through 12 ranged between 0.32 and 0.25 , suggesting less variation in children's progress in $21^{\text {st }}$-CSs when performing experience task activities.

As shown in Table 2, the standard deviation decreased between Experiences 5 (SD = $0.38)$ and $12(\mathrm{SD}=0.25)$, indicating that children's $21^{\text {st }}$-CLOC development variation decreased. Further investigation is warranted.

\section{DISCUSSION}

The descriptive statistics and infield observations showed that the eTBLA enhanced children's opportunity to acquire $21^{\text {st }}$-CLOCs. This result affiliated with Vygotsky's zone of proximal development, where there is no set age or developmental stage when 
children are ready to gain complex thinking skills. The settings of this research provided more time for children to transfer their acquired knowledge and skills and then apply them in novel situations. Children asked questions, sought help, worked individually, and worked with peers and groups, which reflected the induction of cognitive opportunities among them, supporting Mullis and Martin's (2019) findings. Children met the suggested $21^{\text {st }}$-CLOCs of the ability to solve problems, think critically, collaborate effectively across networks, analyze information, and give presentations to the class. Thus, children adopted the classroom instruction and showed evidence of the development of new scientific knowledge and $21^{\text {st }}$-CLOCs, putting what they knew and learned into practice, thereby confirming the findings of the Partnership for $21^{\text {st }}$ Century Skills (2009), Dede (2010), Pearlman (2010), and Al Kandari and Al Qattan (2019). Ultimately, children utilized ICT skills confidently in different experience e-tasks and learning environments, especially e-portfolios.

The results reveal that children's performance progressed over a short period, suggesting that they adapted to the learning context quickly. This result is consistent with the findings of Sanabria and Arámburo-Lizárraga (2017), Al Rewashed et al. (2017), and Walker (2017). A significant increase in mean scores started at the end of the Experience 3 e-task and continued at a steady pace through Experience 12. Therefore, three tasks over a 6-week period are sufficient to ensure that children develop the related knowledge and skills. This result concurred with previous findings (Al Kandari \& Al Qattan, 2018; Ajlouni \& Ajarrah, 2012).

The eTBLA and the training helped participants adapt to the new learning environment and reinforced best practices among teachers and with parents at home. Furthermore, teachers were able to observe children's $21^{\text {st }}$-CLOCs being put into practice. In addition, the results indicated positive parent involvement in terms of asking related questions, scaffolding their children's understanding, and following up with them.

A shift occurred in the learning context because the eTBLA environment provided learners with authentic, challenging, and relevant experiences with hands-on and mental activities. The eTBLA also became an interactive social context because teachers had the opportunity to not only manage children's engagement, but also scaffold their learning. Patrick (2013) confirmed that interactions among children created a positive environment in which they could collaborate, talk, and engage in tasks. In this study, by incorporating technology, the classroom expanded to reach a greater community and established connections with parents at home through different ICT applications. Thus, children's interactions while participating in eTBLA activities may include a wide range of personal skills, including conflict resolution, problem solving, and cooperative learning strategies. When children worked together, they were more likely to ask their peers for help than the teacher. Levy and Murnane (2004) considered ICT to be a rewarding scheme for children's academic skills; Shawareb (2011), and Chau (2014) came to similar conclusions. Ajlouni and Ajarrah (2012) recognized the impact of using the Kid Smart program to facilitate children's access to and use of ICT tools in kindergarten; they identified significant differences in degree-information processing and communication skills as well as ICT access and use. Al Kandari and Al Qattan 
(2019) found that integrating ICT into the classroom learning environment promoted children with learning disabilities as well.

\section{CONCLUSION}

The results indicated that, in the eTBLA, where $21^{\text {st }}$-COC was interwoven with ICT in teaching and learning practices, teachers, children, and parents were engaged in scaffolding children's knowledge and skills during experience task assignments. The goal was to shape children's foundation skills, which included basic academic skills, thinking skills, and personal quality, as described by Loveland (2017).

In summary, we conclude that children come to kindergarten with huge potentials to acquire $21^{\text {st }}$-CSs and, as educators, we need to rethink the context in which learning takes place. Using technology has become essential, and we cannot segregate it from the learning environment. However, children are now expected to be capable of using emerging ICTs and related skills, and there is a need for additional training to enhance their $21^{\text {st }}$-CLOCs.

The challenge remains in fostering the learning environment to host such practices as well as support teachers with ICT and its related applications for a better learning environment. It is important to provide a sufficient budget to equip and train teachers for $21^{\text {st }}$-CLOCs and increase parental involvement in a positive way.

\section{Implications}

- Educators should rethink the degree to which schools provide authentic opportunities for children to acquire $21^{\text {st }}$-CLOCs through various learning experiences. The proposed eTBLA may be an alternative.

- The learning process cannot be limited exclusively to the classroom setting; collaboration in the use of technology can help educate children across contexts.

- Educators should rethink efforts to shift from traditional teaching to teaching based on competencies and proficiencies.

- The $21^{\text {st }}$-CLOCs require extensive professional development for teachers so that they can integrate the curriculum with new instructions, pedagogies, and authentic assessments, thereby having a more significant impact on children's learning.

- The stakeholders at the Ministry of Education should carefully plan and implement the $21^{\text {st }}$-CLOC model to ensure both quality and sustainability.

- Parents can play a significant role in helping their children acquire $21^{\text {st }}$-CLOCs.

\section{Recommendations for future studies}

- Research should be conducted in other school districts with larger samples to make comparisons among Ministry of Education districts.

- Research should be conducted for different curricula, subjects, and content.

- In today's world of digital technology use in the early years, educators should reexamine the way children learn and how learning communities should be prepared and structured. 
Research should be conducted to explore the effects of approaches other than eTBLA on 21 st-century learning outcomes.

\section{REFERENCES}

Adams, D., \& Hamm, M. (2019). Shaping the future with mathematics, science, and technology, solutions, and lesson plans to prepare tomorrow's innovators. [in Arabic] Riyadh, Saudi Arabia: Arab Bureau of Education for the Gulf States

Al Kandari, A. (2013). The effect of e-activities on student achievement and motivation toward learning. Educational Journal, 109(1), 13-50.

Al Kandari, A., \& Al Qattan, M. (2019). Utilizing e-portfolios to enhance science cognition and metacognition of kindergarten children. Educational Journal, 24(3) 2945 .

Al Rewashed, N., Kandari, A., \& Hashem, F. (2017). Exploring in- and pre-service science and mathematics teachers' technology, pedagogy, and content knowledge (TPACK): what next? Journal of Mathematics Science and Technology Education, 13(9), 6113-6131.

Ajlouni, K., \& Aljarrah, A. (2012). The impact of using the Kid Smart Program on facilitating children's access and use of ICT tools according to Jordanian public kindergarten teachers' viewpoint. Education, 132(2), 241.

Ananiadou, K., \& Claro, M. (2009). 21st century skills and competences for new millennium learners in OECD countries. OECD Education Working Papers, 41. doi.org/10.1787/218525261154

Bell, S. (2010). Project-based learning for the 21st century: skills for the future. Clearing House: A Journal of Educational Strategies, Issues and Ideas, 83(2), 39-43. doi.org/10.1080/00098650903505415

Chalkiadaki, A. (2018). A systematic literature review of 21 st century skills and competencies in primary education. International Journal of Instruction, 11(3), 1-16.

Chau, C. L. (2014). Positive technological development for young children in the context of children's mobile apps (Unpublished doctoral dissertation). Tufts University.

Coklar, A., \& Sahin, Y. (2014). Technology literacy according to students: what is it, where are we and what should we do for parents and children? Turkish Online Journal of Qualitative Inquiry, 5(2), 27-34.

Dede, C. (2010). Comparing frameworks for 21st century skills. 21 st Century Skills: Rethinking How Students Learn, 20, 51-76.

Geisinger, K. (2016). 21st century skills: What are they and how do we assess them? Applied Measurement in Education, 29(4), 245-249. 
Hyun, E., \& Davis, G. (2005). Kindergartners' conversations in a computer-based technology classroom. Communication Education, 54(2), 118-135. doi.org/10.1080/03634520500213397

Jang, H. (2016). Identifying 21st century STEM competencies using workplace data. Journal of Science Education and Technology, 25(2), 284-301. http://dx.doi.org/10.1007/s10956-015-9593-1

Jonsson, A., \& Svingby, G. (2007). The use of scoring rubrics: reliability, validity and educational consequences. Educational Research Review, 2(2), 130-144. doi.org/10.1016/j.edurev.2007.05.002

Levy, F., \& Murnane, R. (2004). The new division of labor: how computers are creating the next job market. Princeton, NJ: Princeton University Press.

Lewin, K. M. (2000). New technologies and knowledge acquisition and use in developing countries. Compare: A Journal of Comparative and International Education, 30(3), 313-321. doi.org/10.1080/713657464

Lombardi, M. M. (2007). Authentic learning for the 21st century: an overview. EDUCAUSE Learning Initiative, 1, 1-12.

Loveland, T. R. (2017). Teaching personal skills in technology and engineering education: is it our job? It is every teacher's responsibility to prepare youth to be professional and ethical in their future dealings in classrooms or the workplace. Technology and Engineering Teacher, 76(7), 15.

Mullis, I. V., \& Martin, M. O. (2019). TIMSS 2019 assessment frameworks. Boston, MA: TIMSS \& PIRLS, International Study Centre, Lynch School of Education, Boston College.

Meyers, N. M., \& Nulty, D. D. (2009). How to use (five) curriculum design principles to align authentic learning environments, assessment, students' approaches to thinking and learning outcomes. Assessment \& Evaluation in Higher Education, 34(5), 565-577.

Nikolopoulou, K. (2014). ICT integration in preschool classes: examples of practices in Greece. Creative Education, 5(6), 402-410. doi.org/10.4236/ce.2014.56050

Nir, A., Ben-David, A., Bogler, R., Inbar, D., \& Zohar, A. (2016). School autonomy and 21 st century skills in the Israeli educational system. International Journal of Educational Management, 30(7), 1231-1246. doi.org/10.1108/IJEM-11-2015-0149

Palaiologou, I. (2016). Children under five and digital technologies: implications for early years pedagogy. European Early Childhood Education Research Journal, 24(1), 5-24. doi.org/10.1080/1350293X.2014.929876

Partnership for $21^{\text {st }}$ Century Skills. (2009). State initiatives: overview of state leadership initiative. Retrieved from ttp://www.21stcenturyskills.org/index.php?option=com_contentandtask=viewandid=505 andItemid $=189$. 
Patrick, B. (2013). Chatbot technology: a possible means of unlocking student potential to learn how to learn. Educational Research, 4(2), 218-221.

Pearlman, B. (2010). Designing new learning environments to support 21st century skills. 21st Century Skills: Rethinking how students learn, 116-147.

Rotherham, A. J., \& Willingham, D. (2009). 21st century skills: the challenges ahead. Educational Leadership, 67(1), 16-21.

US 21st Century Workforce Commission. (2000). A nation of opportunity: Building America's 21 st century workforce.

Safar, A. H., Al-Jafar, A. A., \& Al-Yousefi, Z. H. (2017). The effectiveness of using augmented reality apps in teaching the English alphabet to kindergarten children: a case study in the State of Kuwait. Eurasia Journal of Mathematics, Science \& Technology Education, 13(1), 417-440. http://dx.doi.org/10.12973/eurasia.2017.00624a

Sanabria, J. C., \& Arámburo-Lizárraga, J. (2017). Enhancing 21st century skills with AR: using the gradual immersion method to develop collaborative creativity. Eurasia Journal of Mathematics, Science and Technology Education, 13(1), 487-501. doi.org/10.12973/eurasia.2017.00627a

Shawareb, A. (2011). The effects of computer use on creative thinking among kindergarten children in Jordan. Journal of Instructional Psychology, 38(3-4), 213221.

Wagner, T. (2008). Rigor redefined. Educational Leadership, 66(2), 20-24.

Walker, T. D. (2017). Teach like Finland: 33 simple strategies for joyful classrooms. New York: WW Norton \& Company.

Wildenger, L. K., \& McIntyre, L. L. (2012). Investigating the relation between kindergarten preparation and child socio-behavioral school outcomes. Early Childhood Education Journal, 40(3), 169-176. doi.org/10.1007/s10643-012-0509-x 